\title{
Convolvulus sabatius subsp. mauritanicus (Boiss.) Murb. - just a new casual alien plant in Dalmatia or...?
}

\author{
DARIO HRUŠEVAR ${ }^{1}$ \\ DALIBOR VLADOVIĆ 2 \\ NEDILJKO ŽEVRNJA ${ }^{2}$ \\ DIANA VLAHOVIĆ ${ }^{3}$ \\ BOŽENA MITIĆ ${ }^{1}$ \\ ${ }^{1}$ University of Zagreb, Faculty of Science, \\ Department of Biology, Marulićev trg 9a, \\ 10000 Zagreb, Croatia \\ ${ }^{2}$ Nature History Museum Split, \\ Poljana kneza Trpimira 3, 21000, Split, Croatia \\ ${ }^{3}$ OŠ Bogumila Tonija, Ivana Perkovca 90, \\ 10430 Samobor, Croatia

\section{Correspondence:} \\ Božena Mitić \\ E-mail: bozena.mitic@biol.pmf.hr
}

Key words: Ground Morning Glory, Croatia, non-native plant, weed, flora

Received February 02, 2017.

Revised September 13, 2017.

Accepted September 13, 2017.

\section{Abstract}

Background and Purpose: The genus Convolvulus (Convolvulaceae) is distributed worldwide. Several species are used as ornamental plants, and one of them is C. sabatius, a native species in Magreb (Africa) and Italy. For Croatia, it was reported just as a cultivated plant. After six years of continuous monitoring, we present here the first locality of its subspecies C. sabatius subsp. mauritanicus, outside of cultivation.

Materials and Methods: The floristic survey of the city of Kastela was conducted during the summer of 2011 and 2016, and the site was geocoded by a GPS device. The population of the new alien Convolvulus taxon was continuously observed for six years.

Results: The new alien Convolvulus taxon was recorded in 2011 in the settlement Rudine of Kaštel Novi (Dalmatia), on an anthropogenic meadow. At first, it was determined as $\mathrm{C}$. sabatius, and it was its first finding outside of cultivation. In 2016 the plant was more precisely determined as C. sabatius subsp. mauritanicus. From a few individuals observed in 2011, after six years the population of the new alien taxon enlarged its size, and in 2016 covers an area of approximately $6 \mathrm{~m}^{2}$.

Conclusion: Due to our observation that this plant on the surrounding areas of our locality Rudine is constantly planted, we assumed that C. sabatius subsp. mauritanicus, is just a casual alien plant. However, due to the enlargement of its population and weed "behaviour" in similar climatic areas of Europe and Australia, further monitoring of the locality is recommended, and possible eradication measures in the future, as well.

\section{INTRODUCTION}

The cosmopolitan genus Convolvulus L. (Convolvulaceae) is distrib1 uted worldwide, on both the northern and southern hemispheres, and represented with approximately 200 taxa (1). The greatest diversity of the genus is in the Irano - Turanian and Mediterranean regions, with the largest number of species being found in Iran. The genus Convolvulus is generally of relatively small economic value (2), and just a few species are reported to have importance for grazing in desert conditions in Central Asia (3) and Arabia (4). Several species produce attractive flowers and are cultivated in suitable climates, and one of them is $C$. sabatius Viv. (Ground Morning Glory) (2), a native species of Magreb (northwest Africa) and Italy, popular for its beautiful funnel-shaped, violet-blue flowers (2). 
In Croatian flora, seven taxa of the genus Convolvulus are presented (5). However, the alien plant $C$. sabatius is not among them, probably because it was reported once, just as a cultivated plant of the urban area of Omiš (6). Therefore, after six years of continuous monitoring, we present here the first locality of $C$. sabatius in Croatia outside of cultivation (the settlement Rudine of Kaštel Novi), with a precise plant description, taxonomical and distribution notes, habitat analysis and alien preferences.

\section{MATERIAL AND METHODS}

The floristic survey of the city of Kaštela was conducted during the summers of 2011 and 2016, and the site was geocoded by a GPS device. The population of the new alien Convolvulus taxon was observed continually for six years. Plant identifications were done by standard determination keys, e.g. Flora Europaea (7) and Flora d' Italia (8). However, more precise determination of the new Convolvulus taxon was performed in 2016, using the Convolvulus monograph (2), in which details about C. sabatius complex (1) were integrated. Plants that grew on the same site with the new taxon were also determined and quoted. The nomenclature of plant names follows the Flora Croatica Database (5). Collected plant specimens were deposited in the herbarium of the Natural History Museum Split (NHMS).

\section{RESULTS AND DISCUSSION}

During the floristic survey of the Splitsko-dalmatinska County, conducted during the summer of 2011 in the city of Kaštela, in the settlement Rudine of Kaštel Novi, the small population of the new alien Convolvulus taxon was noted. At first, we determined it as $C$. sabatius. Before our finding, this alien species was reported just as an ornamental plant of the urban area of Omiš (6), without the ability to spread out. We recorded this species for the first time outside of cultivation. The coordinates of the site are $43^{\circ} 33^{\prime} 41^{\prime \prime} \mathrm{N}$ and $16^{\circ} 18^{\prime} 43^{\prime \prime} \mathrm{E}$. A few individuals were observed in 2011, and since then the locality has been permanently monitored. After six years, during the early summer of 2016, the plants of $C$. sabatius were still growing, the population enlarged its size, and it now covers an area of approximately $6 \mathrm{~m}^{2}$. In 2016 the taxon was more precisely determined as $C$. sabatius subsp. mauritanicus (Boiss.) Murb. (Fig.1).

The plant is perennial, pubescent, with branched, woody stocks. Its flexuous stems are at least $10 \mathrm{~cm}$ long, and can sometimes reach up to $80 \mathrm{~cm}(7,8)$. Leaves are orbicular to oblong, mostly $0.5-3 \times 0.3-2.2 \mathrm{~cm}$ large $(2)$ and abruptly narrowed into a distinct petiole. The lamina is cuneate to truncate at the base, 1-3 times as long as it is wide and 3-8 times as long as the petiole (7). Peduncles

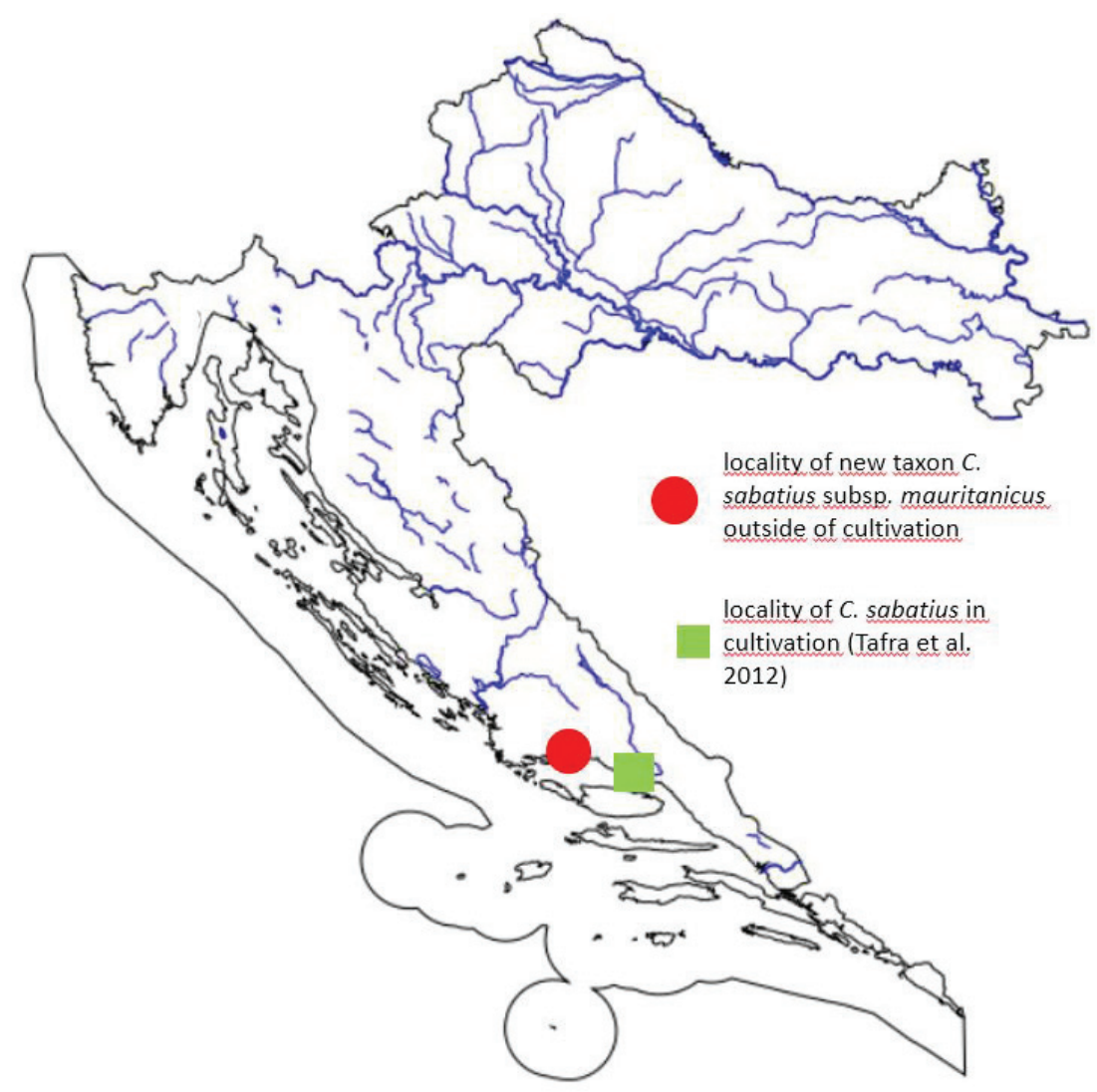

Figure 1. Locations of Convolvulus sabatius in culture (Tafra et al. 2012) and of a new taxon C. sabatius subsp. mauritanicus outside of cultivation (our record). 


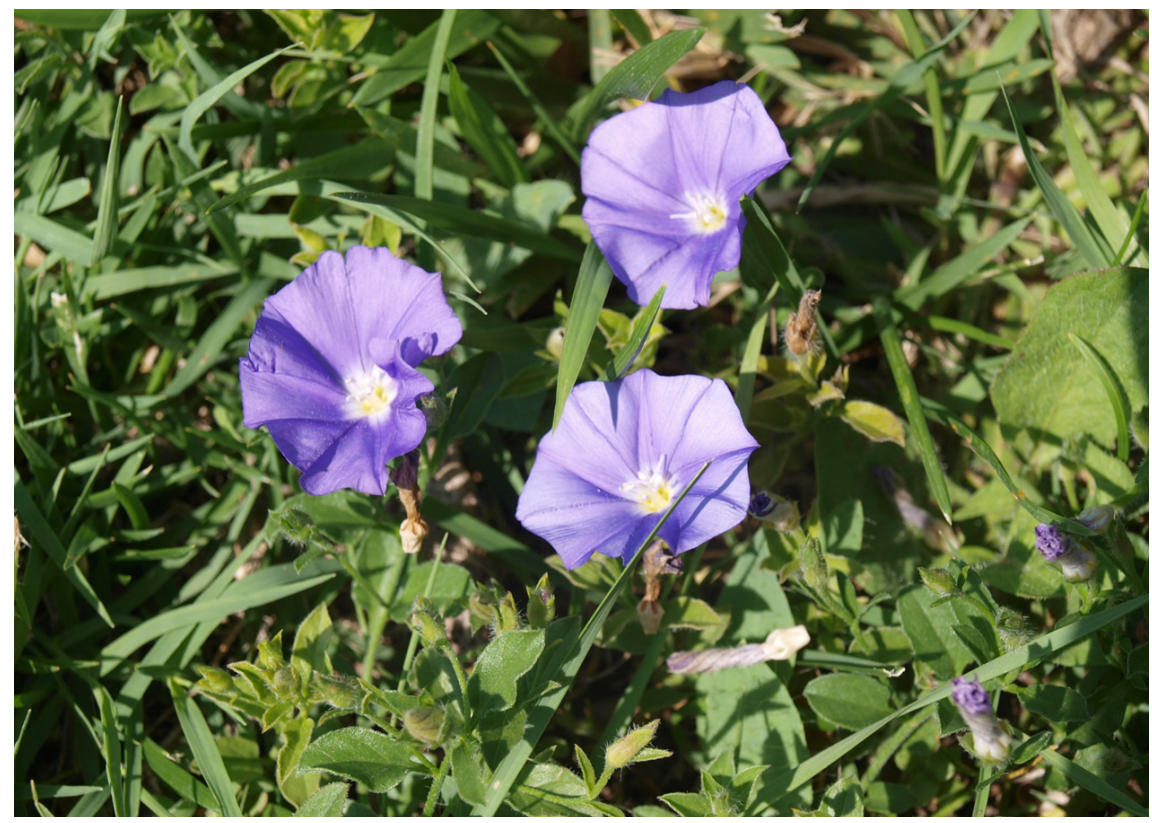

Figure 2. Convolvulus sabatius subsp. mauritanicus on the meadow in the settlement Rudine of Kaštel Novi (Photo by D. Vladović).

are axillary, 0.5 to $3.5 \mathrm{~cm}$ long, 1-3 flowered in shortly pedunculate axillary dichasial cymes (2). Outer sepals are usually acute, inner usually acuminate, $5-7 \times 2-2.5 \mathrm{~mm}$ large $(7,2)$. Corolla is mostly blue or pink-violet, 13-22 $\mathrm{mm}$ large. The blooming season is from April to June (8).

Although some authors considered the taxon C. mauritanicus Boiss. as a synonym of $C$. sabatius Viv. (9), Carine and Robba (1) distinguish two subspecies of the $C$. sabatius complex: C. sabatius subsp. sabatius and C. sabatius subsp. mauritanicus (Fig. 2).

The same taxonomy on the subspecies level is accepted by the World Checklist of Selected Plant Families (10) and some other recent plant taxonomy bases, e.g. IOPI Global Plant Checklist (11) and GBIF Backbone Taxonomy (12), and was integrated in the monograph about the genus Convolvulus (2) as well. Those two subspecies are very similar in morphology and the most useful distinguishing features are hairs. Namely, in C. sabatius subsp. sabatius sepals are pubescent with appressed hairs and glabrous margins (2), while $C$. sabatius subsp. mauritanicus has prominent protruding hairs on the calyx and often also on the stem and leaves (Fig. 3).

The taxon C. sabatius subsp. sabatius naturally grows only in northwest Italy (10), or precisely on the Ligurian
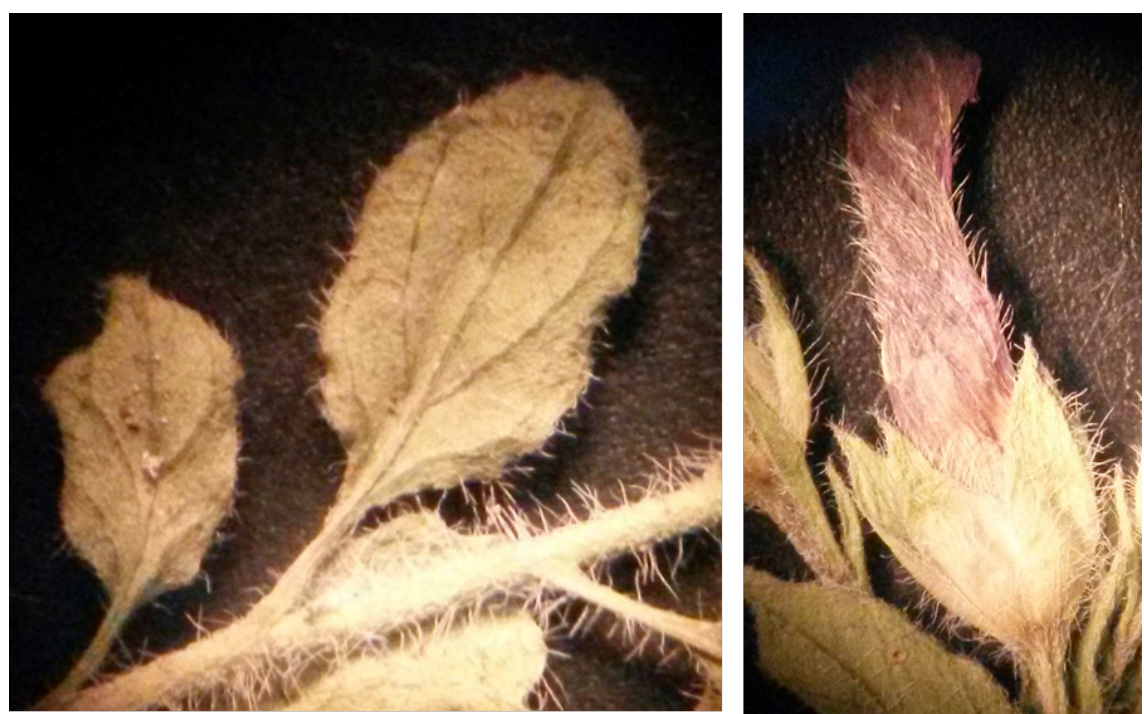

Figure 3. Convolvulus sabatius subsp. mauritanicus: prominent protruding hairs on the stem, leaves, calyx and corolla (Photo by D. Hruševar). 
coast $(2,13)$. However, as a cultivated plant it can be found escaped from cultivation in other parts of Italy, e.g. Lazio, Puglia and Sicily (13). The widely cultivated taxon C. sabatius subsp. mauritanicus is native in Algeria and Morocco (2), but it was also reported as an escaped plant in Sicily (2, 11), Australia (14), and Greece (15).

In natural habitats $C$. sabatius grows on dry, calcareous rocks, in Europe from the sea level up to $300 \mathrm{~m}$ a.s.l. (7, 8) and on Magreb (Northwest Africa) it can be found on high altitude, sometimes above 2300 m. a.s.l. (2). However, the Dalmatian population was found on the anthropogenic meadow where plants from the classes Papaveretea rhoeadis S. Brullo et al. 2001 (syn. Stellarietea mediae R. Tx. et Preising in R. Tx. 1950) and Artemisietea vulgaris Lohm. et al. in R. Tx. 1950 prevail (cf. 16, 17). The taxon Convolvulus sabatius subsp. mauritanicus covers an area of approximately $6 \mathrm{~m}^{2}$. Floristic composition of other accompanying plants on the researched habitat was represented by: (i) frequent taxa: Cynodon dactylon (L.) Pers., Digitaria sanguinalis (L.) Scop., Cichorium intybus L., Lolium perenne L., Oxalis corniculata L.; and (ii) less frequent and rare taxa: Medicago lupulina L., Poa bulbosa L., Dactylis glomerata L., Sherardia arvensis L., Picris echioides L., Hedypnois cretica (L.) Dum. Cours., Taraxacum officinale Weber, Sonchus asper (L.) Hill ssp. glaucescens (Jord.) Ball, Reichardia picroides (L.) Roth, Pallenis spinosa (L.) Cass., Hypericum perforatum L., Ajuga chamaepitys (L.) Schreb., Anagallis arvensis L., Plantago lanceolata L., Diplotaxis tenuifolia (L.) DC., Avena barbata Pott ex Link and Torilis nodosa (L.) Gaertn.

Due to our observation that this plant on the surrounding inhabited areas is constantly growing, and according to the definitions for alien flora (18), we assumed that $C$. sabatius subsp. mauritanicus, observed for the first time in the flora of Croatia, is just a casual alien plant, depending on the cultivation in the nearest settlement. However, due to the enlargement of its population and weed "behaviour" in similar climatic areas of Australia and Europe, it might become the first established population in Dalmatia. Namely, species C. sabatius (regardless of subspecies taxonomical level) has been recorded as weed, escaping from cultivation in Australia (14), and as naturalized alien plant in Greece (15), which has, at least partly, similar climatic conditions as Dalmatia. So, our caution is needed and further monitoring of the locality is recommended, and possible eradication measures in the future, as well.

\section{REFERENCES}

1. CARINE MA, ROBBA L 2010 Taxonomy and evolution of the Convolvulus sabatius complex (Convolvulaceae). Phytotaxa 14: 1-21. https://doi.org/10.11646/phytotaxa.14.1.1

2. WOOD JRI, WILLIAMS BRM, MITCHELL TC, CARINE MA, HARRIS DJ, SCOTLAND RW 2015 A foundation monograph of Convolvulus L. (Convolvulaceae). PhytoKeys 51: 1-278. https://doi.org/10.3897/phytokeys.51.7104
3. GRIGORIEV C 1953 Convolvulacea. In: Shishkin BK. et al. (eds) Flora USSR volume 19: Tubiflorae. USSR Scientific Academy, Moscow and Leningrad, 1-37

4. DICKSON V 1955 The wild flowers of Kuwait and Bahrain. George, Allen and Unwin, London, 1-144

5. NIKOLIĆ T, (ed.) 2016 Flora Croatica Database. Department of Biology, Faculty of Science, University of Zagreb. URL:http://hirc. botanic.hr/fcd (Accessed 09/11/2016)

6. TAFRA D, PANDŽA M, MILOVIĆ M 2012 Vascular flora of the town of Omiš. Nat Croat 21(2): 301-334

7. STACE CA 1972 Convolvolus L. In: Tutin TG, Heywood VH, Burges NA, Moore DM, Valentine DH, Walters SM, Webb DA (eds) Flora Europaea, Vol. 3. Diapensiaceae to Myoporaceae. Cambridge University Press, Cambridge

8. PIGNATTI S 1982 Flora d'Italia 2. Edagricole, Bologna

9. HYAM RD 1984 Convolvulus Linnaeus. In: Cullen J, Alexander JCM, Brickel CD, Edmondson JR, Green PS, Heywood VH, Jorgensen P-M, Jury SL, Knees, SG, Maxwell HS, Miller DM, Robson NKB, Walters SM, Yeo PF (eds) The European Garden Flora VI - Dicotyledons (Part IV). Cambridge University Press, Cambridge

10. STAPLES G 2016 World Checklist of Convolvulaceae. Facilitated by the Royal Botanic Gardens, Kew. Published on the Internet. http://apps.kew.org/wcsp/ Retrieved 2017-01-25

11. HASSLER M. 2017 World Plants: Synonymic Checklists of the Vascular Plants of the World (version Nov 2016). In: Species 2000 \& ITIS Catalogue of Life, 23rd December 2016 (Roskov Y, Abucay L, Orrell T, Nicolson D, Bailly N, Kirk P, Bourgoin T, DeWalt RE, Decock W, De Wever A, Nieukerken E van (eds) Digital resource at www.catalogueoflife.org/col. Species 2000: Naturalis, Leiden, the Netherlands (Accessed 25/01/2017)

12. GBIF Backbone Taxonomy 2016. GBIF Secretariat Checklist Dataset doi:10.15468/39omei (Accessed via http://www.gbif.org/dataset/d7dddbf4-2cf0-4f39-9b2a-bb099caae36c on 2017-01-25)

13. NIMIS PL, ATTORRE F, BLASI C, CELESTI L, FANELLI G, LATTANZI E, MORO A, PITTAO E, TILIA A, MARTELLOS S 2017 Portale della Flora di Roma. http://dryades.units.it/Roma (Accessed 25/01/2017)

14. RANDALL RP 2007 The introduced flora of Australia and its weed status. CRC for Australian Weed Management Department of Agriculture and Food, Western Australia 2007, 127, https://www.une. edu.au/_data/assets/pdf_file/0019/52372/2007.-The-introducedflora-of-Australia-and-its-weed-status.pdf (Accessed 31/01/2017)

15. ARIANOUTSOU M, BAZOS I, DELIPETROU P, KOKKORIS Y 2010 The alien flora of Greece: taxonomy, life traits and habitat preferences. Biol Invasions 12: 3525-3549. https://doi.org/10.1007/s10530-010-9749-0

16. ANONYMOUS 2009 Annex I of the Ordinance on Amendments to the Ordinance on habitat types, habitat map, threatened and rare habitat types and measures for conserving habitat types (In Croatian). Official Gazette 119/09

17. MUCINA L, BÜLTMANN H, DIERSSEN K, THEURILLAT J P, RAUS T, ČARNI A, ŠUMBEROVÁ K, WILLNER W, DENGLER J GAVILAN GARCIA R, CHYTRY M, HAJEK M, DI PIETRO R, IAKUSHENKO D, PALLAS J, DANIËLS FJA, BERGMEIER E, SANTOS GUERRA A, ERMAKOV N, VALACHOVIC M, SCHAMINEE JHJ, LYSENKO T, P. DIDUKH YP, PIGNATTI S, RODWELL JS, CAPELO J, WEBER HE, SOLOMESHCH A., DIMOPOULOS P, AGUIAR C, HENNEKENS SM, TICHY L 2016 Vegetation of Europe: hierarchical floristic classification system of vascular plant, bryophyte, lichen, and algal communities. Appl Veg Sci 19 (S1): 3-264

18. MITIĆ B, BORŠIĆ I, DUJMOVIĆ I, BOGDANOVIĆ S, MILOVIĆ M, CIGIĆ P, REŠETNIK I, NIKOLIĆ T 2008 Alien flora of Croatia: proposals for standards in terminology, criteria and related database. Nat Croat 17(2): 73-90 